\title{
An extensive prevalence of Borrelia burgdorferi, the etiologic agent of Lyme borreliosis, in Nagano Prefecture, Japan
}

\author{
Kimito Uchikawa, ${ }^{*}$ Koichi Muramats,${ }^{* *}$ Kenji Miyamoto*** \\ and Minoru NaKaO *** \\ * Department of Parasitology, Shinshu University School of Medicine, Matsumoto 390, Japan \\ ** Department of Infectious Disease, Nagano Research Institute of Health and Pollution, \\ Nagano 380, Japan \\ *** Department of Parasitology, Asahikawa Medical College, Asahikawa 078, Japan
}

(Received: March 16, 1991)

Key words: Lyme borreliosis, prevalence, Borrelia burgdorferi, tick vector, Ixodes persulcatus, Ixodes ovatus.

\begin{abstract}
To seize the prevalence of B. burgdorferi in Nagano Prefecture, we examined $I$. persulcatus and $I$. ovatus ticks for spirochetal infection in 1990 . The ticks swept at 20 sites were tested by culturing their midgut tissues or by an indirect immunofluorescence assay using the monoclonal antibody, H5332. The spirochete was detected in the ticks from 18 sites. The infection rates for the adult ticks of I. persulcatus and I. ovatus were $21.3 \%$ (68/319) and $25.1 \%$ (76/303), respectively. Such the high prevalence of the spirochete in the tick vectors was comparable to that in the Western Europe.
\end{abstract}

\section{INTRODUCTION}

It was reported that the first case of Lyme borreliosis from Japan had been contracted in Nagano Prefecture probably by Ixodes persulcatus (Kawabata et al., 1987). Horiuchi and Ando (1987) compiled 7 cases of erythema chronicum migrans (ECM), an early clinical marker of Lyme borreliosis, which were preceded by the tick bite in the southeastern region of Nagano Prefecture, and presented later 4 cases serologically diagnosed as Lyme disease in the same region (Horiuchi et al., 1988). In addition to these

* 内川公人：信州大学医学部寄生虫学教室 (元390 松本市地 3-1-1)

** 村松紘一：長野県衛生公害研究所微生物部 ( 380 長野市安茂里米村 1978)

*** 宮本健司, 中尾稳: 旭川医科大学寄生虫学教室 ( $\mathbf{T} 078$ 旭川市西神楽 4 線 5 号 3-11) reports, ixodid ticks are known to be abundant and human tick bites have been frequently encountered in this mountainous prefecture (Uchikawa and Sato, 1983; Yamaguti, 1980).

Referring to these facts, we recognized it necessary to initiate multifarious studies of Lyme borreliosis in Nagano Prefecture from the view point of community medicine. We set up a study group composed of staff members from Shinshu University and began our study with the propagation of information on Lyme disease to local physicians through distribution of guidelines and a questionnaire regarding this disease (Uchikawa et al., 1990; Nakama et al., 1991). Besides making efforts to find out cases of Lyme borreliosis, we have proceeded to ascertain the extent of the disease in the prefecture. Since this borreliosis is a typical zoonosis, we have diverse means of detecting the etiologic agent itself and 
specific antibodies to it. It seemed, however, to be most efficient to demonstrate spirochetes in unfed ticks from various parts of Nagano Prefecture.

Specimens of Ixodes persulcatus Schulze, Ixodes ovatus Neumann, Haemaphysalis flava Neumann, Haemaphysalis japonica Warburton and Haemaphysalis kitaokai Hoogstraal were taken and examined for spirochetes in the present survey. Results for the two Ixodes ticks are given below, whereas those for the Haemaphysalis species should be supplemented with much more data to elucidate the role of these ticks in the natural cycle of $B$. burgdorferi. The present paper includes some of the data already used in Mivamoto et al. (1991, and in preparation).

\section{Materials and Methods}

Tick survey areas were marked beforehand on the map of Nagano Prefecture (Fig. 1). While driving through the 20 appointed survey areas mainly in June, 1990, lanes and tracks in forests at the elevations of 800$2,000 \mathrm{~m}$ which appeared to have locally abundant populations of ticks were located. Questing ticks were collected by flagging low vegetations on and along those lanes and tracks. Acquired ticks were kept at $4^{\circ} \mathrm{C}$ and $100 \%$ RH until examination.

For culturing spirochetes, the ticks washed briefly in $70 \%$ ethanol were dissected individually under the dissecting microscope with sterile precautions. Midgut tissues triturated by forceps were inoculated into $6 \mathrm{ml}$ of Barbour-Stoenner-Kelly (BSK) medium (Barbour et al., 1983a) containing $50 \mu \mathrm{g} / \mathrm{ml}$ of rifampin, or $150 \mu \mathrm{g} / \mathrm{ml}$ of 5 -fluorouracil and $150 \mu \mathrm{g} / \mathrm{ml}$ of phosphomycin, in a culture tube. The cultures were maintained at $32^{\circ} \mathrm{C}$ and checked weekly for the presence of spirochetes under the darkfield microscope for 4-6 weeks.

The midgut tissues of live ticks not processed to the culture were smeared individually in one of 12 wells on an afluorescent slide (Matsunami, Japan) and allowed to air dry. After acetone-fixation for $10 \mathrm{~min}$, the slides were kept at $4^{\circ} \mathrm{C}$ until the following indirect immunofluorescence assay (IFA). The smears were treated with the monoclonal antibody, $\mathrm{H} 5332$, reactive with the outer

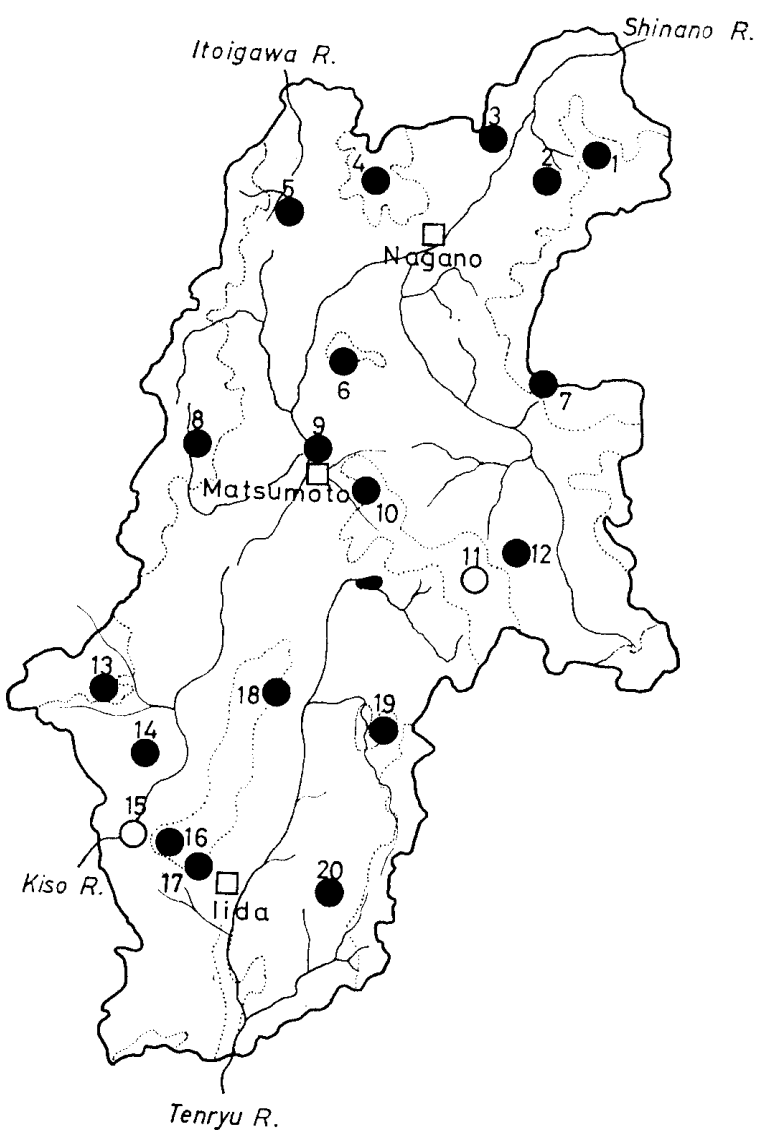

Fig. 1 Location of survey sites in Nagano Prefecture, with indication of sites positive (solid circles) and negative (open circles) for Borrelia burgdorferi in Ixodes ticks.

Dotted lines indicate borders of the national and prefectural parks.

surface protein A (OspA) of B. burgdorferi serotype B31 (Barbour et al., 1983b), and then the bound antibody was detected with fluorescein isothiocyanate-labeled anti-mouse IgG (Zymed, USA). The stained spirochetes were observed with the aid of the fluorescence microscope (Olympus BH2-RLF, Japan).

Collection of ticks and preparation for IFA were accomplished by $\mathrm{KU}$ and KMR, cultures for spirochetal isolation were done by $\mathrm{KMR}, \mathrm{KMY}$ and $\mathrm{MN}$, and IFA was completed by MN.

\section{Results}

Either or both I. persulcatus and I. ovatus were taken at all of the collecting sites throughout Nagano Prefecture (Table 1). Acquired ticks consisted of adults, nymphs and larvae in $I$. persulcatus, while all $I$. 


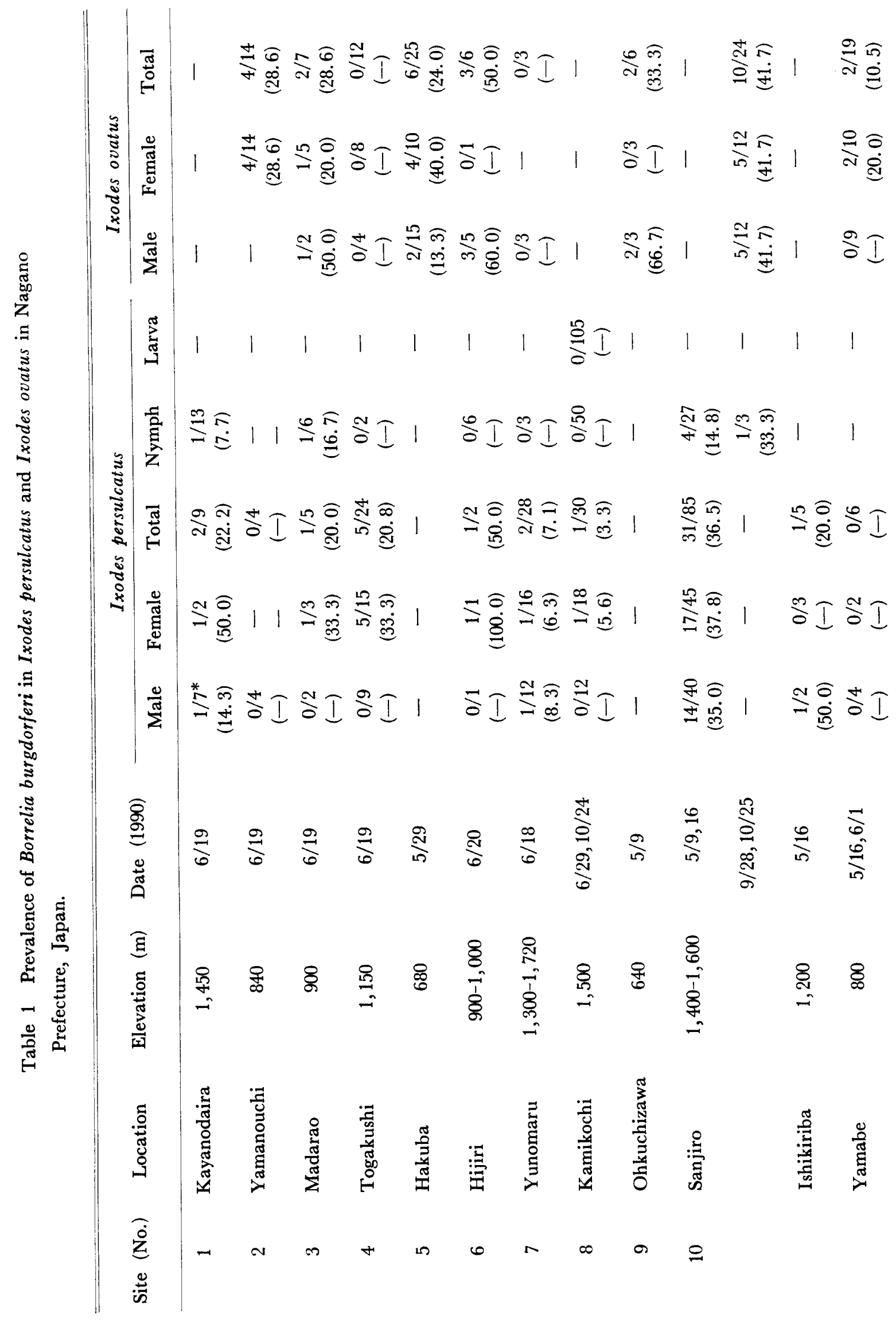




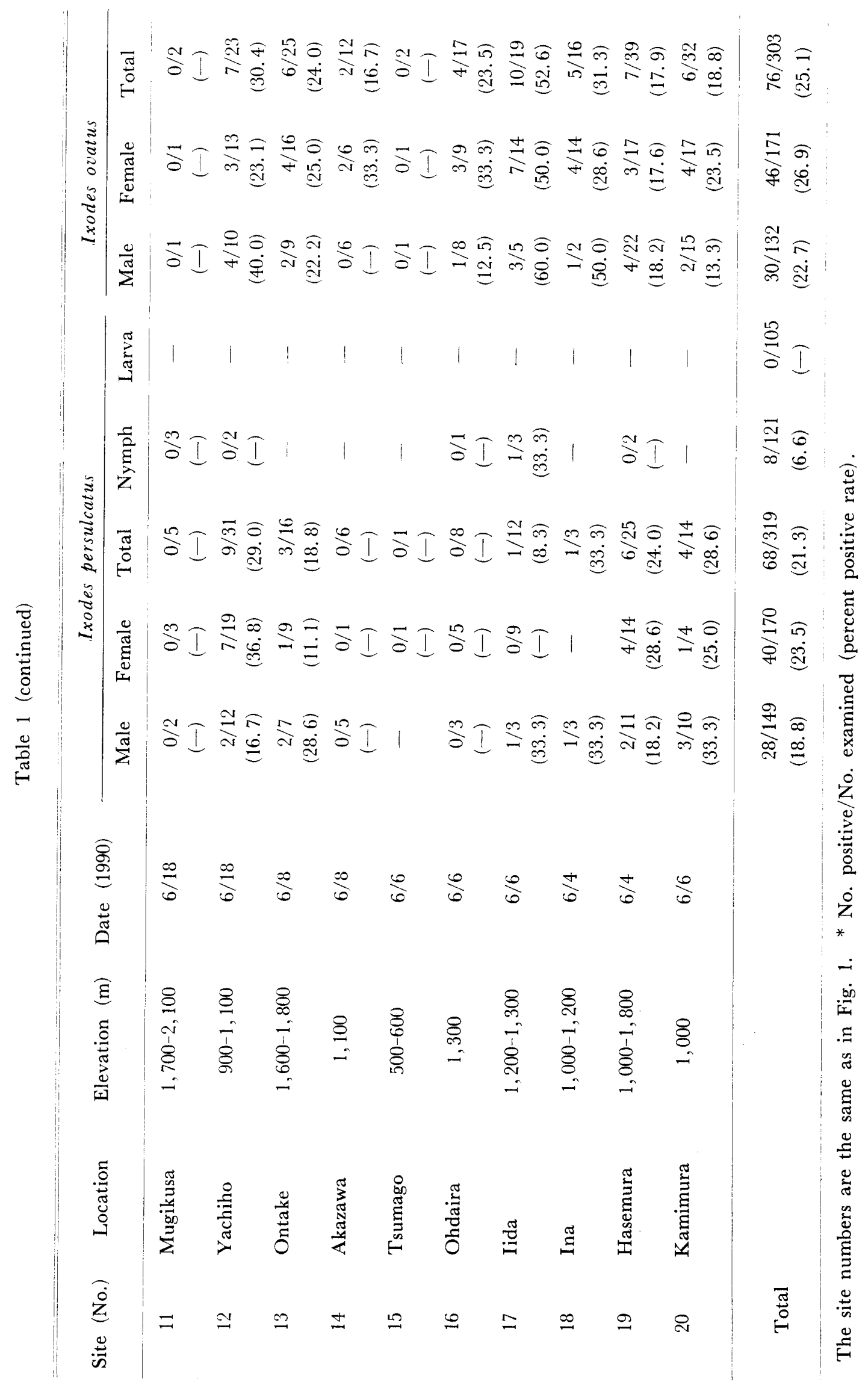


ovatus were adults. A total of 149 males, 170 females, 121 nymphs and 105 larvae of I. persulcatus and 132 males and 171 females of $I$. ovatus was examined for spirochetal infection.

Of those ticks, 78 males and 138 females of $I$. persulcatus and 36 males and 131 females of $I$. ovatus were submitted for culturing of spirochetes. Twelve males (15.4\%) and 35 females $(25.4 \%)$ of $I$. persulcatus and 13 males $(36.1 \%)$ and 36 females $(27.5 \%)$ of I. ovatus yielded spirochetes. All the isolates were regarded as being identical with $B$. burgdorferi based on the results of IFA.

The remaining 71 males, 32 females, 121 nymphs and 105 larvae of $I$. persulcatus, and 96 males and 40 females of $I$. ovatus were examined for $B$. burgdorferi spirochete by IFA. Sixteen males $(22.5 \%), 5$ females $(15.6 \%), 8$ nymphs $(6.6 \%)$ and no larva $(0 \%)$ of $I$. persulcatus, and 17 males $(17.7 \%)$ and 10 females $(25.0 \%)$ of $I$. ovatus were positive for the spirochete.

Table 1 lists all the ticks tested and the identification of $B$. burgdorferi within those ticks by both culturing and IFA. The overall spirochete-infection rates in the adult ticks of I. persulcatus and I. ovatus in Nagano Prefecture were $21.3 \%(68 / 319)$ and $25.1 \%$ (76/303), respectively.

Geographically, B. burgdorferi was discovered in almost the entire Nagano Prefecture (Fig. 1). Of 20 collecting sites, only Sites 11 and 15, where limited numbers of ticks, 10 and 3, respectively, were taken and examined, yielded no positive data. Yet the spirochete was cultured or detected frequently from the ticks taken at the sites close to these two (Fig. 1). The infection rates in adult $I$. persulcatus and $I$. ovatus ranged from 20 to $30 \%$ in many sites. However, the rates were extremely high at the higher part of Site 10 (Sanjiro) (36.5\% for adult I. persulcatus and $41.7 \%$ for adult $I$. ovatus) and Site 17 (52.6\% for adult I. ovatus). Half of the adult ticks were infected with the spirochete at Site 6, although the number of ticks examined was small. Compared with infection rates for adult ticks at other sites, those at Sites 7 and 8 were low, recorded as $6.5 \%(2 / 31)$ for ticks of the two species and $3.3 \%(1 / 30)$ for $I$. persulcatus ticks, respec- tively. Moreover, no spirochete was detected in 50 nymphs and 105 larvae of $I$. persulcatus from Site 8 .

\section{Discussion}

An extensive prevalence of $B$. burgdorferi in Nagano Prefecture was demonstrated in the present study. Thus, the risk of contracting Lyme borreliosis can be predicted for any part of the prefecture. There was, however, a remarkable difference in the spirochete-infection rates in ticks from different survey sites. Although more collecting and tests are still necessary, it is reasonable to presume at present that there are higher risks of coming in contact with infected ticks in the mountains in the central part of the prefecture including Sites 6, 9 and 12 that yielded the spirochete so frequently (Table 1 , Fig. 1).

The next important finding was that $I$. persulcatus and $I$. ovatus were infected with $B$. burgdorferi with the high rates almost equivalent to each other. However, the rate for $I$. persulcatus might be slightly underestimated because of non-reactivity of a part of spirochetes in this tick with $\mathrm{H} 5332$ as shown by Nakao et al. (in preparation). Miyamoto et al. (in preparation) already noted this on the basis of recovery of the spirochete by culturing midgut tissues from 145 adult $I$. persulcatus ticks and 85 adult I. ovatus ticks acquired in Nagano Prefecture. We reconfirmed their result in the present study by increasing tick samples. This significant phenomenon has so far been observed only in Nagano Prefecture, since it was reported that $I$. persulcatus ticks yielded many more positive cultures than I. ovatus in Hokkaido (Miyamoto et al., in preparation). However, we presume that both $I$. ovatus and $I$. persulcatus play at least equivalent roles in the maintenance of the spirochete in nature in some districts of Japan. Only a single major tick vector has been incriminated in each endemic area of Lyme borreliosis in the northern hemisphere so that the finding of the two significant tick vectors within Nagano Prefecture is noteworthy. Consequently, the ticks responsible for Lyme borreliosis as well as human tick bites should be identified clearly in each case 
especially in Nagano Prefecture. Ecologically, I. persulcatus occurs above the elevation of $800 \mathrm{~m}$ and is more prevalent in the forests around $1,500 \mathrm{~m}$. On the other hand, $I$. ovatus shares the higher elevations with $I$. persulcatus but is not as locally abundant at higher elevations as compared to $I$. persulcatus in Nagano Prefecture. I. ovatus extends lower to foothill habitats where activity areas of many local residents are included (Uchikawa and Sato, 1983). Reflecting these distribution patterns of the two ticks, human tick bites in May and June were reported as being caused mostly by $I$. ovatus, and those in July exclusively by $I$. persulcatus in Nagano Prefecture (Nakama et al., 1991). Lyme borreliosis that is preceded by tick bite is likely to be caused by the two ticks with the same seasonality as above.

The spirochete-infection rates ranging from 20 to $25 \%$, on average, in the adult ticks of both $I$. persulcatus and $I$. ovatus in Nagano Prefecture are distinctly higher than those in Ixodes scapularis and Ixodes pacificus in the Southeast and the Pacific Coast of the United States, respectively. The rates are slightly lower than those in the notorious Ixodes dammini in the Northeast of the United States, given in many reports such as Tsai et al. (1989). Among the data available so far, the infection rates in Ixodes ricinus in the Western Europe are almost equivalent to those found in Nagano Prefecture. In South Germany, 2,400 individuals of $I$. ricinus were examined for $B$. burgdorferi infection, and the infection rates for the adults, nymphs and larvae were recorded as $20.9,10.6$ and $1.1 \%$, respectively (Stanek et al., 1988). In Nagano Prefecture, a total of 121 nymphs of $I$. persulcatus was examined for the spirochete, and only $8(6.6 \%)$ were positive. However, 50 negative nymphs were those from Site 8 where a very low prevalence was recorded in the adult ticks (Table 1). So the infection rate for remaining 71 nymphs from the other sites was $11.3 \%$ $(8 / 71)$ subequal to that for nymphal I. ricinus from South Germany. Although 105 unfed larvae from Site 8 yielded no positive data unlike those from South Germany, it is still necessary to examine more individuals of this stage from highly infected populations for the spirochete. Uchikawa et al. (1990) suggested that the epidemiological picture for Lyme borreliosis in Nagano Prefecture might be the same as in Europe based on similarity of ecological properties of tick vectors. It is not contradictory to the above assumption that the same level of spirochetal prevalence in the tick vectors has been confirmed in both Nagano Prefecture and Europe. Moreover, Nakano et al. (in preparation) demonstrated the heterogeneity of OspA as well as the non-reactivity with H5332 among some isolates from $I$. persulcatus from Japan as observed so far merely in European strains of B. burgdorferi.

Finally, we should pay attention to the locations of our survey sites in Nagano Prefecture and of the prefecture itself in the mainland Honshu. Many sites that yielded the spirochete were located in parts of national and prefectural parks where many people from various parts of Japan get very easily by car in the active season of $I$. persulcatus and $I$. ovatus. Japanese people make close observation of plants and flowers on roadsides and pick up seasonal wild vegetables in forests. So, we are easily brought into close contact with $I$. persulcatus or $I$. ovatus infected with $B$. burgdorferi under these circumstances. On the other hand, Nagano Prefecture is bordered with the 8 other prefectures at the central part of the mainland Honshu. It is highly probable that the prevalence of $B$. burgdorferi in tick vectors will be recorded at the same level as in Nagano Prefecture in some parts of those 8 prefectures.

\section{Agknowledgements}

We thank Dr. A. G. Barbour, Department of Medicine and Microbiology, University of Texas Health Science Center, San Antonio, Texas, for providing us with the monoclonal antibody, H5332, Drs. H. Nakama, N. Maruchi and T. Saida, members of Lyme borreliosis study group from Shinshu University School of Medicine, Matsumoto, and Dr. R. W. Husband, Adrian College, Adrian, Michigan, for helpful discussions and critically reading the manuscript.

\section{REFERENCES}

Barbour, A. G., W. Burgdorfer, S. F. Hayes, O. Peter and A. Aeschlimann (1983a): Isolation 
of a cultivable spirochete from Ixodes ricinus ticks of Switzerland. Curr. Microbiol., 8: 123126.

Barbour, A. G., S. L. Tessier and W. J. Todd (1983b): Lyme disease spirochetes and ixodid tick spirochetes share a common surface antigenic determinant defined by a monoclonal antibody. Inf. Immunol., 41 : 795-804.

Horiuchi, N. and Y. Ando (1987): Statistic analysis of 19 human tick bites observed in our own clinic. Hifu-Byo Shinryo, 9: 557-561 (in Japanese).

Horiuchi, N., Y. Ando, M. Mori, M. Ohtani, K. Arimitsu and K. Ohtsuka (1988): Human tick bites and presence of Lyme disease in Japan. Jpn. J. Dermatol., 98: 209 (in Japanese).

Kawabata, M., S. Baba, K. Iguchi, N. Yamaguti and H. Russell (1987): Lyme disease in Japan and its possible incriminated tick vector Ixodes persulcatus. J. Infect. Dis., 156: 854.

Miyamoto, K., M. Nakano, N. Sato and M. Mori (1991): Isolation of Lyme borreliosis spirochetes from tick vectors and feral rodents in Japan. In: Modern Acarology (eds., Dusbábek, F. and V. Bukuva), The Haugue and Academia, Prague (in press).

Nakama, H., K. Uchikawa, N. Maruchi and T. Saida (1991): A review of Lyme disease in Nagano Prefecture based on preliminary findings in 1990. Ann. Environ. Sci., Shinshu Univ., 13: 134-139 (in Japanese).

Stanek, G., M. Pletschette, H. Flamm, A. M. Hirschl, E. Aberer, W. Kristoferitsch and E. Schmutzhard (1988): European Lyme borreliosis. Ann. N. Y. Acad. Sci., 539: 274-282.

Tsai, T. F., R. E. Bailey and P. S. Moore (1989): National surveillace of Lyme disease, 1987-1988.
Conn. Med., 53: 324-326.

Uchikawa, K., H. Nakama, N. Maruchi and T. Saida (1990): Lyme disease: An aid to physicians for better understanding and detection of the new tick-born disease. Ann. Environ. Sci., Shinshu Univ., 12: 22-35 (in Japanese).

Uchikawa, K. and K. Sato (1983): On tick fauna of Nagano Prefecture, with reference to distribution pattern of causative species of human tick-bite cases. Bull. Environ. Conserv., Shinshu Univ., 5: 78-82 (in Japanese with English summary).

Yamaguti, N. (1980): Tick-bite examples. Kankyo-Eisei, 27: 20-24 (in Japanese).

\section{摘}

\section{長野県におけるライム病菌の浸淫状況}

長野県に抒けるライム病菌 Borrelia burgdorferiの 浸淫状況を把握するために，末吸着マダ二類の感染率 を調べた. 主として 1990 年 6 月に，県下 20 地点で, 標高 $800 \sim 2,000 \mathrm{~m}$ の範用の林内でマダ二類の多そう な小道を探し，路上または道沿いの草木上に待機する 個体をハタズリ法で採集した．得られたマダニの中腸 を用い，分離培着法または単クローン抗体 H5332を用 いる間接螢光抗体法によってライム病菌を検出した.

20地点のうち，18地点のシュルツェマダニ，ヤマト マダニの一方または双方からライム病菌が検出され， 長野県のほぼ全域に病原菌による污染のあることが判 明した．マダ二属成虫が20〜25\%の感染率を示し， 2 種がほぼ同率で污染されていることが地域的な特色で あるとみられた．このように高いマダ二属の感染率 は, 西ヨーロッパの Ixodes ricinus のそれに匹敵す るものであった。 